\title{
A conversation with Stuart Kornfeld
}

S chool of Medicine, is best known for his research in glycobiology, in particular his work describing pathways involved in oligosaccharide biosynthesis, processing, and maturation. These actions are critical in mediating proper folding and transport of proteins. Kornfeld (Figure 1) also discovered how lysosomal enzymes are routed from where they are produced to where they are needed in lysosomes, which help rid cells of macromolecules. See the full interview on the JCI website (http://www. jci.org/videos/cgms) for more of Kornfeld's stories about his first experiment, stuttering, and why St. Louis has such magnetism.

JCI: Where did you grow up?

Kornfeld: I grew up in St. Louis. My father was a dentist in private practice, but also was a professor at Washington University and St. Louis University. He spent part of his time seeing patients, part of his time teaching and doing research. My mother was his assistant. She ran his office and helped him at the chair.

JCI: Did they encourage you to go into dentistry?

Kornfeld: No. To be honest, my father admired physicians and I think always steered me toward medicine rather than dentistry. I was a pretty good student, but my interests were really in sports. I lived in an area where there were a lot of kids, and this was before television. We were always outside playing, and St. Louis is a big baseball town. I was pretty good, so I got to play with the older boys, and I spent as much time as I could practicing so I could keep up with them. Science really wasn't on my radar until much later.

For college, I went to Dartmouth with a zoology major. The course that really turned me on to science was biochemistry. It opened up a new world to me. I was impressed that in our textbook, there was a large section dealing with the work of Carl and Gerty Cori, who were at Washington University Medical School. The text focused on the work they did on glycogen metabolism that led to the 1947 Nobel Prize. Taking that course and knowing that I was going to Washington University for medical school, I tried to get a job the summer before school started in the biochemistry department. As luck would have it, my biochemistry professor at Dartmouth set it up, so I started doing real research for

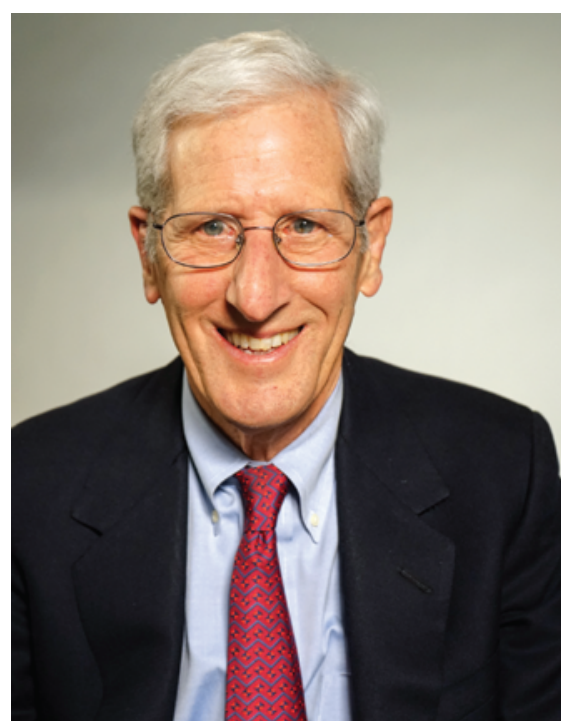

Figure 1. Stuart Kornfeld on April 25, 2015. Image credit: Karen Guth.

the first time right before medical school.

I did research every opportunity I had. I worked in a lab with a mentor, Luis Glaser. He had just gotten his PhD and was starting out on his own. We were in one little room; he would show me how to do various techniques. Each summer, I worked in the lab, and our senior year, we had an elective period that I used to work in his lab.

JCI: Did you ever meet the Coris?

Kornfeld: Gerty had died the year before I came, but Carl Cori's office was right next to Luis's lab, and yes, I met him, but he was very intimidating in the beginning. Dr. Cori wrote a letter for me to get a position at the $\mathrm{NIH}$, which at the time was very competitive, and I'm sure that had a lot to do with being accepted there. At the NIH, I worked with another biochemist named Vic Ginsburg. He was also very young and had just come to the NIH. He worked in glycobiology, and it was a small lab. There was one other postdoc when we arrived. When I say we arrived... I met my wife, Rosalind, at Wash U in the Biochemistry department. She was a graduate student right across the hall, and we had common interests. When we went to the $\mathrm{NIH}$, we decided we would both work in the same lab.

JCI: Why glycobiology?

Kornfeld: At that time, most of the emphasis in glycobiology was on energy metabolism and how glycogen is made and broken down. The other area that was being studied was bacterial cell walls and yeast cell walls. In fact, my project had to do with how yeast make the polysaccharide mannan. I realized that mammalian cells also are coated with sugar moieties on their surface, called the glycocalyx, and there wasn't much known about that at all. People had seen it with various dyes and through electron microscopy. I also learned that blood group determinants were composed of sugars and that the difference between your blood group type being A or B is just a single sugar variant. It seemed to me that these sugars on the surfaces of cells must have an important role, and there were relatively few people working in that area. I thought that would be a great new area to explore.

JCI: You and Rosalind ended up back at Washington University for your first faculty positions?

Kornfeld: I should mention that we got our positions in a very different way than most people go about it today. We both had great admiration for Washington University and sensed that it was a good place for young people to get started. There was a wonderful chairman of medicine, Carl Moore, whom I had trained with. And we liked St. Louis. So while we were at the $\mathrm{NIH}$, we contacted Dr. Moore and asked if he would be interested in having us come back on the faculty. He said yes and had lab space available for both of us if I was interested in hematology along with glycobiology. When we first started, Rosalind had her own project and I had my own project, so we figured we would work together on certain things and go our separate ways on others, but always be in communication. It wasn't formally planned in 
any way; it just happened, and in the end, it worked out extremely well.

If I had to name one research project that was most pivotal, it was a study that was done with a terrific MD-PhD student in the lab, Ira Tabas. We were investigating how lysosomal enzymes are tagged for delivery to lysosomes. It was known from work of Elizabeth Neufeld that lysosomal enzymes have some sort of tag on their sugar chains. Lysosomal enzymes are glycoproteins, which means they have covalently bound sugar chains linked to the protein, and Neufeld showed that there is a tag on these sugar chains that allows the enzymes to bind to receptors that transport them to the lysosome. The tag was mysterious until Bill Sly showed that the tag is a modified mannose residue with a phosphate on it. This suggested that there must be a kinase that adds the phosphate, and a bunch of labs tried to find this kinase, and none were successful. This is where Ira and I jumped in. We thought that if we could figure out in what stage in the synthesis of the lysosomal enzyme the tag is added that we could then look in that area of the cell and find the enzyme that adds the tag.

Ira labeled cells with tritiated mannose, which gets incorporated in lysosomal enzymes, and then isolated a lysosomal enzyme and first asked, "Does it have this tag on it?" Sure enough, he was able to show this enzyme acquired the mannose6-phosphate. As a control, to prove that it was mannose-6-phosphate, he treated the enzyme with a phosphatase, which Sly had shown removed the phosphate. To his surprise, the phosphatase did not remove the phosphate. My reaction was that Ira had screwed up the experiment somehow. He repeated the experiment and got the same result. After puzzling over this for days, we finally got the idea that maybe the phosphate is blocked by another residue, and this started a hunt for what that residue could be, and it turned out to be another sugar called $N$-acetylglucosamine.

The beautiful thing about this was it immediately suggested an entire new biosynthetic pathway for how cells add a phosphate onto this sugar mannose. Marc Reitman and Ajit Varki joined the team, and in no time at all, we found a whole new enzyme pathway that accounts for how cells tag these lysosomal enzymes. To prove this was right, we looked in patients that Neufeld had described, who can't add a tag to their lysosomal enzymes and therefore secrete them into the blood. Their plasma has enormous levels of lysosomal enzymes, and their cells lack lysosomal enzymes. Ajit and Marc showed that the defect in these patients is lack of this first enzyme that we had found. The exciting thing about this experiment was that it changed the way in which we think about how sugars are modified.

JCI: I actually talked to Ira before this interview. He told me that you had a very quiet demeanor that belied your incredible excitement about science, but that you also had the infuriating habit of analyzing his data before he got a chance to.

Kornfeld: Well, I know I've been accused of that. We've always worked as a group in the lab, and I communicate a lot with the people in the lab. I think that's one of the most satisfying things about working in a lab. My original impression of what happens in a lab is, you go into a room all by yourself and do experiments and great things happen, and that's it. In actual fact, there's enormous interaction among people in the lab, and that's very rewarding. There are many different ways you can mentor students, and they can all be successful. I just happen to have a style where I like to interact with each person in the lab individually. Some of these experiments take days and days and days to do. So yes, occasionally, I would rush in to look at the results at the end, sometimes before the postdoc, but I do try to avoid that.

JCI: Just as active as you were within the lab, you've also shepherded the MDPhD students as well as clinician-scientists seeking lab training.

Kornfeld: I was mentored by two wonderful physician-scientists, Carl Moore and Sol Sherry. They were both physicianscientists who maintained clinical roles in the department and had done important basic medical research. This had a big impact on me. I also feel that the clinical exposure is important for advancing medical research and that physician-scientists have a special role. I attended in medicine for many years and attended on our hematology service until just a couple of years ago. I feel that the MD-PhD program is the best way today for people to prepare themselves for careers as physician-scientists, that they need the strong background in research training and also to have a good understanding of clinical medicine.
Instead of just talking about it, I thought I should be involved in these training programs. I was head of our MD-PhD program for seven years. In the year 2000, we started a new program in the Department of Medicine called the Physician Scientist Training Program, which is for graduates of $\mathrm{MD}-\mathrm{PhD}$ programs who are going to get further clinical training and also postdoc laboratory training. It's a way of mentoring them and keeping their interest in medical research, and it's been very successful.

JCI: You were part of another scientific couple, beyond the one with your wife. You and Phil Majerus ran the Division of Hematology for many years.

Kornfeld: Phil joined the department the same time that Rosalind and I came, and he had trained with Roy Vagelos in lipid biochemistry, and we just hit it off. We were both trained as biochemists, and we both felt that biochemical approaches to understanding normal physiology as well as disease were a way to advance medical research. Neither of us had had a lot of training in hematology before we came, and Dr. Moore was willing to let us learn on the job to be clinical hematologists. Happily, we both liked hematology. It worked out, we did well, and we were promoted to be heads of the division at fairly young ages. Phil had more interest in the business side. He took care of all the financial things, I took care of the fellowship program, and together, we recruited. Things went extremely well. We complemented each other. We were able to recruit quite a few outstanding faculty. It was a very good collaborative operation for many years.

JCI: If you could not be a physician or a scientist doing research, what sort of career path do think you would have followed?

Kornfeld: I think I would have tried to be an architect. When I was a teenager, I came across some articles about Frank Lloyd Wright. The displays of the houses he had done struck me as beautiful. At Dartmouth, I took a course on art and architecture, and I really got to understand how architecture is developed, and there was a big section on Frank Lloyd Wright. I've always admired him and that field. I don't know if I would have had the talent to do that. I certainly would never have been a Frank Lloyd Wright, but it's something I think would be very satisfying.

\section{Ushma S. Neill}

